\title{
THE LOCATION OF LPG FILLING STATIONS AND POTENTIAL RISKS OF INCIDENTS
}

The risk of unsuitable placement of LPG (i.e. Liquid Petroleum Gas) propane-butane filling stations in densely populated areas or in the immediate vicinity of busy roads may have, in the event of fire or explosion, incalculable consequences in terms of fatal or serious accidents and cause considerable economic damage to property. As a consequence, the positioning of any such LPG filling station should always be of crucial importance already in the filling station planning stage and its placement should be carefully assessed. The present paper aims at outlining a particular method of evaluating risks resulting from incorrect placement of an LPG filling station, including potential consequences. One such approach to assessment of installation safety of LPG filling stations is to implement the so called ALOHA screening method. This paper shall demonstrate practical implementation of the ALOHA screening, and that with regard to infrastructure, it is not always possible to find a suitable and safe location for LPG filling stations.

Keywords: ALOHA, safe LPG filling station location, emergencies, safe distance.

\section{Introduction}

The purpose of the following section is to describe, with the use of a model situation, the placement of an LPG filling station (Fig. 2) and to stress the importance of paying particular attention to safe placement of this installation for risks and incidents elimination with respect to the infrastructure, the occurrence of incidents and their adverse effects.

The word 'incident' in the context of the presently discussed situation conveys the extraordinary conditions and impact on the affected area, as well as on general public. The magnitude of the incident is the consequence of destructive effect and the nature of the affected area [1].

The consequences of the emergence of extraordinary conditions are numerous and they may be classified according to the following Fig. 1:

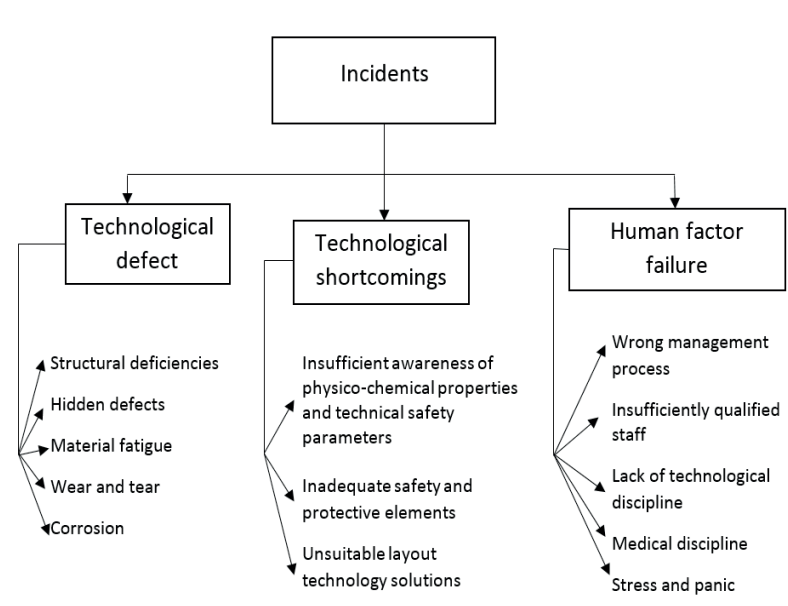

Fig. 1 The Emergence of Incidents [1]

For practical modeling of the ALOHA screening, a fictitious LPG filling station situated in a populated urban area close to a shopping center was chosen. The location of the LPG filling station was specified by a 50-metre distance from the shopping center and 10 meters from the road with normal city traffic. In terms of technical specification, a single-dispenser-unit

\footnotetext{
* ${ }^{1}$ Ondrej Varta, ${ }^{2}$ Sarka Krocova

${ }^{1}$ State Labour Inspection Office, Opava, Czech Republic

${ }^{2}$ VSB Technical University of Ostrava, Ostrava - Poruba, Czech Republic

E-mail: ondrej.varta@suip.cz
} 
LPG filling station was considered, with a 4000-liter reservoir. The application of the ALOHA method will demonstrate the importance of resolving the matter of safe location for the LPG filling station prior to any construction works.

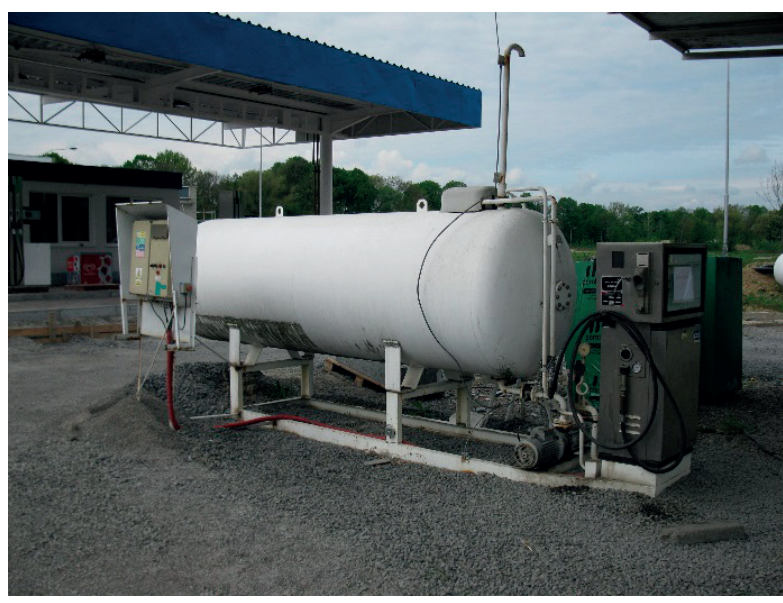

Fig. 2 An illustrative photograph of an LPG filling station (source: author - O. Varta)

\section{ALOHA Screening Method and its Features}

The ALOHA software application (Areal Locations Of Hazardous Atmospheres) is a dispersive model for Windows operating system that was developed by the United States Environment Protection Agency (US EPA) [2].

The software uses a series of Gauss distribution equations to evaluate the movement of pollutants released into the air.

The software works with inputs specified in the following fixed order:

- Site location data (place name, country, type of buildings);

- Information on the released agent (the software has a large database of chemical substances, including the necessary physical and chemical properties);

- Information on the state of atmosphere (the grade of air temperature stratification stability following the Pasquill's scale, wind strength and direction, air temperature, degree of cloud cover, etc.);

- Information on the source of the leakage; it is possible to enter 4 source types and their parameters (direct source, puddle, reservoir, pipeline).

The ALOHA software allows to have results in both textual and graphic form. It renders a cloud of an agent of specified concentration, dosage, and source capacity.

The limitations of the ALOHA software include:
- The software works with low wind velocities and stable atmospheric conditions;

- Small resolution of terrain topography;

- The software does not take into account changes in wind direction, impact of fire and chemical reactions, dispersion of solid particles and/or solutions;

- The agent leakage time is set to a period of 1 hour and the dispersion distance is restricted to $10 \mathrm{~km}$.

The latest version of ALOHA software (5.4 of February 2006) added fire and explosion modeling functionality.

Apart from threats of toxicity, users may also evaluate fire hazards associated with the so called jet fires, puddle fires, vapor cloud explosions (VCE), boiling liquid expanding vapor explosions (BLEVE) and flashfires.

The ALOHA software is available free of charge on the US EPA official website [3]

\section{Practical Steps for the Use of the ALOHA Method}

The location selected for the LPG filling station was Opava, Moravian-Silesian Region, Czech Republic, random choice from the main streets available in this town. The practical calculation example involves toxic cloud dispersion and BLEVE explosion modeling (see Fig. 3 and 4).

\section{Calculation pursuant Toxic Cloud Dispersion}

\section{SITE DATA:}

\begin{tabular}{|l|l|}
\hline Location: & TOWN CZECH REPUBLIC \\
\hline Building Air Exchanges Per Hour: & 0.59 (unsheltered single storied) \\
\hline Time: & $\begin{array}{l}\text { December 11, 2014 0931 hours } \\
\text { ST (using computer's clock) }\end{array}$ \\
\hline
\end{tabular}

\section{CHEMICAL DATA:}

\begin{tabular}{|l|l|}
\hline Chemical Name: & PROPANE \\
\hline Molecular Weight: & $44.10 \mathrm{~g} / \mathrm{mol}$ \\
\hline AEGL-1 $(60 \mathrm{~min}):$ & $5500 \mathrm{ppm}$ \\
\hline AEGL-2 $(60 \mathrm{~min}):$ & $17000 \mathrm{ppm}$ \\
\hline AEGL-3 $(60 \mathrm{~min}):$ & $33000 \mathrm{ppm}$ \\
\hline IDLH: & $2100 \mathrm{ppm}$ \\
\hline LEL: & $21000 \mathrm{ppm}$ \\
\hline UEL: & $95000 \mathrm{ppm}$ \\
\hline Ambient Boiling Point: & $-42.7^{\circ} \mathrm{C}$ \\
\hline $\begin{array}{l}\text { Vapor Pressure at Ambient } \\
\text { Temperature: }\end{array}$ & greater than $1 \mathrm{~atm}$ \\
\hline $\begin{array}{l}\text { Ambient Saturation } \\
\text { Concentration: }\end{array}$ & $1,000,000 \mathrm{ppm}$ or $100.0 \%$ \\
\hline
\end{tabular}


ATMOSPHERIC DATA: (MANUAL INPUT OF DATA)

\begin{tabular}{|l|l|}
\hline Wind: & $\begin{array}{l}3 \text { meters/second from } 50^{\circ} \\
\text { true at 3 meters }\end{array}$ \\
\hline Ground Roughness: & $\begin{array}{l}\text { urban or forest } \\
\text { Cloud Cover: 5 tenths }\end{array}$ \\
\hline Air Temperature: & $20^{\circ} \mathrm{C}$ \\
\hline Stability Class: & $\mathrm{D}$ \\
\hline No Inversion Height & $50 \%$ \\
\hline Relative Humidity: &
\end{tabular}

\section{SOURCE STRENGTH:}

Leak from short pipe or valve in horizontal cylindrical tank

Flammable chemical escaping from tank (not burning)

\begin{tabular}{|l|l|}
\hline Tank Diameter: & 1.8 meters \\
\hline Tank Length: & 1.57 meters \\
\hline Tank Volume: & 4.00 cubic meters \\
\hline Tank contains liquid & $20^{\circ} \mathrm{C}$ \\
\hline Internal Temperature: & 1.88 tons \\
\hline Chemical Mass in Tank: & \multicolumn{2}{|l|}{} \\
\hline Tank is 85\% full & centimeters \\
\hline Circular Opening Diameter: & 3 minutes \\
\hline Opening is 0 meters from tank bottom & $\begin{array}{l}755 \text { kilograms/min } \\
\text { (averaged over a minute or } \\
\text { more) }\end{array}$ \\
\hline Release Duration: & 1,706 kilograms \\
\hline Max Average Sustained Release Rate: & $\begin{array}{l}\text { The chemical escaped as a } \\
\text { mixture of gas and aerosol } \\
\text { (two phase flow). }\end{array}$ \\
\hline Total Amount Released: &
\end{tabular}

\section{THREAT ZONE:}

\begin{tabular}{|l|l|}
\hline Threat Modeled: & $\begin{array}{l}\text { Flammable Area of Vapor } \\
\text { Cloud }\end{array}$ \\
\hline Model Run: & Heavy Gas \\
\hline
\end{tabular}

\section{DISPERSION CLOUD RESULTS}

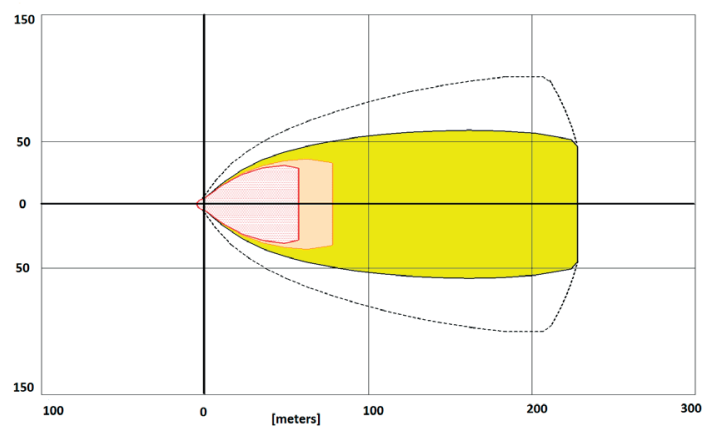

Red: $\quad 58$ meters $-(21000 \mathrm{ppm}=\mathrm{LEL})$

Orange: 79 meters $-(12600 \mathrm{ppm}=60 \% \mathrm{LEL}=$ Flame Pockets $)$

Yellow: 229 meters $-(2100 \mathrm{ppm}=60 \% \mathrm{LEL})$

Fig. 3 Affected area in the vicinity of the LPG filling station [4]

\section{BLEVE- Boiling Liquid Expanding Vapor Explosions}

SITE DATA:

\begin{tabular}{|l|l|}
\hline Location: & $\begin{array}{l}\text { OPAVA, Tesinska ulice } \\
\text { CZECH REPUBLIC }\end{array}$ \\
\hline $\begin{array}{l}\text { Building Air Exchanges Per } \\
\text { Hour: }\end{array}$ & 0.59 (unsheltered single storied) \\
\hline Time: & $\begin{array}{l}\text { December 11, 2014 0931 hours ST } \\
\text { (using computer's clock) }\end{array}$ \\
\hline
\end{tabular}

\section{CHEMICAL DATA:}

\begin{tabular}{|l|l|}
\hline Chemical Name: & PROPANE \\
\hline Molecular Weight: & $44.10 \mathrm{~g} / \mathrm{mol}$ \\
\hline AEGL-1 $(60 \mathrm{~min}):$ & $5500 \mathrm{ppm}$ \\
\hline AEGL-2 $(60 \mathrm{~min}):$ & $17000 \mathrm{ppm}$ \\
\hline AEGL-3 $(60 \mathrm{~min}):$ & $33000 \mathrm{ppm}$ \\
\hline IDLH: & $2100 \mathrm{ppm}$ \\
\hline LEL: & $21000 \mathrm{ppm}$ \\
\hline UEL: & $95000 \mathrm{ppm}$ \\
\hline Ambient Boiling Point: & $-42.7^{\circ} \mathrm{C}$ \\
\hline $\begin{array}{l}\text { Vapor Pressure at Ambient } \\
\text { Temperature: }\end{array}$ & greater than $1 \mathrm{~atm}$ \\
\hline $\begin{array}{l}\text { Ambient Saturation } \\
\text { Concentration: }\end{array}$ & $1,000,000 \mathrm{ppm}$ or $100.0 \%$ \\
\hline
\end{tabular}

\section{ATMOSPHERIC DATA: (MANUAL INPUT OF DATA)}

\begin{tabular}{|l|l|}
\hline Wind: & $\begin{array}{l}3 \text { meters/second from } 50^{\circ} \\
\text { true at } 3 \text { meters }\end{array}$ \\
\hline Ground Roughness: & urban or forest \\
\hline Cloud Cover: & 5 tenths \\
\hline Air Temperature: & $20^{\circ} \mathrm{C}$ \\
\hline Stability Class: & $\mathrm{D}$ \\
\hline No Inversion Height & $50 \%$ \\
\hline Relative Humidity: &
\end{tabular}

\section{SOURCE STRENGTH:}

\begin{tabular}{|l|l|}
\hline \multicolumn{2}{|l|}{ BLEVE of flammable liquid in horizontal cylindrical tank } \\
\hline Tank Diameter: & 1.8 meters \\
\hline Tank Length: & 1.57 meters \\
\hline Tank Volume: & 4.00 cubic meters \\
\hline Tank contains liquid & $20^{\circ} \mathrm{C}$ \\
\hline Internal Storage Temperature: & 1.88 tons \\
\hline Chemical Mass in Tank: & \\
\hline Tank is 85\% full & $100 \%$ \\
\hline Percentage of Tank Mass in Fireball: & 69 meters \\
\hline Fireball Diameter: & 6 seconds \\
\hline Burn Duration: &
\end{tabular}




\section{THREAT ZONE:}

\begin{tabular}{|l|l|}
\hline Threat Modeled: & Thermal radiation from fireball \\
\hline
\end{tabular}

\section{DISPERSION CLOUD RESULTS}

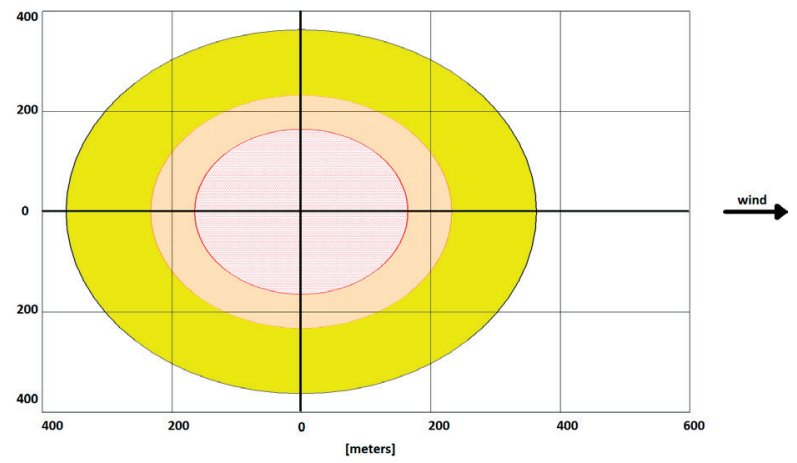

Red: $\quad 165$ meters $-(10.0 \mathrm{~kW} /(\mathrm{sq} \mathrm{m})=$ potentially lethal within $60 \mathrm{sec})$ Orange: 233 meters $-(5.0 \mathrm{~kW} /(\mathrm{sq} \mathrm{m})=2$ nd degree burns within $60 \mathrm{sec})$ Yellow: 363 meters $-(2.0 \mathrm{~kW} /(\mathrm{sq} \mathrm{m})=$ pain within $60 \mathrm{sec})$

Fig. 4 Affected area in the vicinity of the LPG filling station [5]

\section{Conclusions}

We shall now compare the ALOHA method calculation result with the distances entered to delimit the LPG filling station location; the original distances were:

a) 50 meters between the LPG filling station and the shopping center

\section{References}

[1] BARTLOVA, I., PESAK, M.: Risk Analysis and Prevention of Industrial Emergencies II, Risk Analysis and Awareness of Industrial Emergency Situations, EDICE SPBI SPEKTRUM 33, 2003. ISBN 80-86634-30-2.

[2] US EPA http://www.epa.gov/ceppo/cameo/aloha.htm

[3] BERNATIK, A.: Prevention of Serious Emergency Incidents II, University textbook VSB, FBI, VSB Ostrava, 2006.

[4] Affected area in the vicinity of the LPG filling station, http://www.epa.gov/ceppo/cameo/aloha.htm

[5] Affected area in the vicinity of the LPG filling station, http://www.epa.gov/ceppo/cameo/ aloha.htm. b) $10 \mathrm{~m}$ meters from the road with normal city traffic and the calculation of the dispersion cloud with the use of ALOHA method:

Red: 58 meters $-(21000 \mathrm{ppm}=\mathrm{LEL})$

Orange: 79 meters $-(12600 \mathrm{ppm}=60 \% \mathrm{LEL}=$ Flame Pockets $)$

Yellow: 229 meters $-(2100 \mathrm{ppm}=60 \% \mathrm{LEL})$

and the result for the BLEVE phenomenon:

Red: 165 meters $-(10.0 \mathrm{~kW} /(\mathrm{sq} \mathrm{m})=$ potentially lethal within $60 \mathrm{sec})$

Orange: 233 meters $-(5.0 \mathrm{~kW} /(\mathrm{sq} \mathrm{m})=2$ nd degree burns within $60 \mathrm{sec}$ )

Yellow: 363 meters $-(2.0 \mathrm{~kW} /(\mathrm{sq} \mathrm{m})=$ pain within $60 \mathrm{sec})$

From the above it is possible to come to a definite conclusion that the suggested location of the LPG filling station in Opava populated area and the shopping center.

The LPG filling station located as suggested above might be the source of an emergency incident following certain technological break-down causing injuries to a significant number of citizens, including subsequent likely explosion of BLEVE variety.

For the aforementioned reasons involving very high level of risk associated with emergency incidents, it is necessary to make use of feasibility study methods already in the course of assigning the relevant project documentation (e.g. the ALOHA screening method used in the above case study)

It is expected that the procedure set in this manner will lead to a decrease in the level of risks from stationary sources and emergency incidents. is completely unsuitable because of the proximity to a densely 